\title{
Microsatellite analysis of polyandry and spawning site competition in brown trout (Salmo trutta L.)
}

\author{
Carlo R. LARGiadèr ${ }^{\mathrm{a}, \mathrm{b}, *}$, Arnaud Estoup ${ }^{\mathrm{a}}$, Frédéric LeCERF ${ }^{\mathrm{a}}$, \\ Alexis Champigneulle ${ }^{c}$, René GuyOmarD ${ }^{\mathrm{a}}$ \\ ${ }^{\text {a }}$ Institut national de la recherche agronomique, Laboratoire de génétique des \\ poissons, 78352 Jouy-en-Josas Cedex, France \\ b Division of Population Biology, Institute of Zoology, University of Berne, \\ Baltzerstrasse 6, 3012 Berne, Switzerland \\ c Institut national de la recherche agronomique, Station d'hydrobiologie lacustre, \\ 75 avenue de Corzent, 74203 Thonon-les-Bains, France
}

\begin{abstract}
Polyandry and competition for spawning sites in a sedentary brown trout population was studied using four highly variable microsatellite loci. All loci combined gave average exclusion probabilities of 0.91 and 0.97 based on two reference samples of spawners. All eggs from 22 redds of this population were collected. For 10 of these redds, tissue samples of potential mothers, i.e. females that were observed to show spawning behaviour on these redds, were sampled. Only in four cases, the observed four-locus genotype of the putative mother conformed with corresponding egg-genotypes. For all four redds polyandry was detected encompassing two fathering males. We applied a sequential procedure of multiple paternity analysis that allowed the assignment of a single paternal genotype to each individual egg, and thus, to quantify the genetic contribution of different males. In each redd, one male fertilised the majority of eggs $(60-92 \%)$ and the contribution of additional males ranged between $8-40 \%$. The total number of eggs in the four redds represented $11-21 \%$ of the total fecundity of the mothers. This indicates that females in this population spread their eggs among several redds. Eight cases of incomplete redd superimposition were detected among all 22 redds analysed indicating strong competition for spawning sites between females.
\end{abstract}

Salmo trutta / microsatellites / polyandry / sperm competition / redd superimposition

Résumé - Analyse de la polyandrie et de la compétition pour les sites de reproduction chez la truite commune (Salmo trutta L.) à l'aide de marqueurs microsatellites. Une étude de la polyandrie et de la compétition pour les

* Correspondence and reprints

E-mail: largiader@zoo.unibe.ch 
sites de reproduction a été réalisée dans une population naturelle sédentaire de truite commune à l'aide de quatre marqueurs microsatellites. La probabilité moyenne combinée d'exclusion de ces quatre marqueurs était de 0,91 et 0,97 dans deux échantillons de référence de reproducteurs. Tous les œufs de 22 frayères ont été collectés. Pour dix des frayères, des échantillons d'ADN de mères potentielles, c'est-à-dire de femelles montrant un comportement reproducteur sur ces frayères, ont été obtenus. Les génotypes observés aux quatre locus chez ces mères potentielles se sont avérés compatibles avec les génotypes des œufs correspondant dans quatre cas et, pour chacun d'eux, un phénomène de polyandrie impliquant la participation de deux mâles a été mis en évidence. Pour chacune de ces frayères, nous avons pu assigner un génotype paternel unique à chaque œuf et quantifier la contribution de chaque mâle en appliquant un test séquentiel d'analyse de paternité multiple. Les pourcentages d'œufs fécondés du mâle « majoritaire » variait de 60 à $92 \%$. Le nombre total d'œufs trouvés dans les quatre frayères représentait $11-21 \%$ de la fécondité totale des mères. Ceci indique que ces femelles répartissent leur ponte sur plusieurs frayères. Huit cas de surcreusement de frayères ont été détectés parmi les 22 frayères étudiées suggérant une forte compétition des femelles pour les sites de reproduction.

Salmo trutta / microsatellites / polyandrie / compétition de sperme / surcreusement de frayères

\section{INTRODUCTION}

Breeding systems are of central interest in evolutionary biology. They influence the strength and consequences of sexual selection $[1,13,45]$, as well as the effective population size which affects the amount of genetic variability that is transmitted to the next generation $[9,10,49]$. An impressive range of reproductive tactics is shown by fish, and the usually external fertilisation of fish eggs may explain at least partly why in particular sperm competition among different types of males showing alternative mating tactics is extremely widespread in this group [50]. These alternative male mating tactics may result in polyandrous breeding systems. Polyandry in return increases effective population sizes up to twice the values that are expected from purely monogamous or polygynous mating systems [49]. The intensity of competition for favourable spawning sites is another important evolutionary trait that characterises probably many of these breeding systems. It has been proposed for instance that such breeding competition between females is the basis for the evolution of female parental care in salmonids [52].

These questions are of particular interest for salmonid species. Many populations of these species are threatened through anthropogenic pressure such as fishing and habitat destruction, which may reduce the effective population size below a critical threshold, induce inbreeding depression and lead to population extinction $[2,48]$. Therefore, the understanding of how the effective population size is affected and consequently to what extent genetic variability is maintained 
in natural populations by the breeding system is essential for the conservation of genetic diversity in these species. Various male reproductive tactics have been observed in salmonids [26,50] (and references therein). Subdominant males can be roughly differentiated as sneakers and satellite males. Sneakers are considerably smaller than the dominant males and attempt to steal fertilisations by approaching secretly, darting toward the mating pair during oviposition and releasing sperm. Satellite males are similar in size to the dominant males and acquire matings through fighting. These different tactics hence appear to be strongly correlated with the relative difference in size between subdominant and dominant males [22]. Large size differences between mature males occur among and within populations of salmonids due to considerable variation in life history styles $[30,39]$. Individuals may migrate to the sea or freshwater lakes and return for reproduction to their natal streams or alternatively they may be resident. In general, resident individuals have lower growth rates and mature earlier as compared to their migrating counterparts.

The spawning behaviour of brown trout (Salmo trutta L.) is similar to most salmonid species $[3,12,15,27,41]$. Essentially, females bury their eggs in clean gravel batches of the streambed for incubation. When eggs are deposited by the female, a dominant male is simultaneously shedding his sperm alongside of her. Parental care was so far not observed for both sexes and females bury their eggs in one or several redds.

So far, few studies have addressed the detection and estimation of polyandry generated through subdominant males and of competition between females through redd superimposition in salmonid species. These questions are difficult to investigate under strictly natural conditions. For example in Atlantic salmon (Salmo salar), with the exception of a recent study [34], all estimates of the proportion of eggs fertilised by mature male parr (sneakers) in competition with anadromous males by means of genetic markers were obtained under simulated natural mating conditions [26,31,37,51].

The recent development of highly polymorphic codominant markers such as microsatellites has opened new perspectives for the study of breeding systems. This is illustrated by several studies in various species $[6,17,44]$, including fish $[28,29,32]$. In this paper, we investigated the reproductive structure in a stream-resident brown trout population using microsatellites. More specifically, we addressed the questions of (i) the occurrence of polyandry and the estimation of a minimum number of fathering males per redd, (ii) the relative contribution of each fathering male to egg fertilisation in polyandrous redds and (iii) the minimum rate of redd superimposition as a measure of indirect competition between females. 


\section{MATERIALS AND METHODS}

\subsection{Study site and biological material}

The Chevenne Creek is a $2.5 \mathrm{~km}$ long tributary of the upper Dranse d'Abondance (Lake Leman system) and is divided by impassable waterfalls into two parts of equal length. During the spawning season, a total of 34 redds in the upper and 123 redds in the downstream part were located by regular visual inspection (at least twice a week), between 03.11.1995 and 08.01.1996. A steel pole carrying the number of the redd was then placed $20-25 \mathrm{~cm}$ downstream of the tail of the redd and the size of the redd was recorded. The sampling of the eggs of 22 redds (eight redds of the upstream section and 14 redds of the downstream section, respectively) was practised after a minimum of 150 degree-days (i.e. after the spawning season), which was estimated on the basis of daily recordings of the water temperature. A sampling net with an opening of $40 \times 40 \mathrm{~cm}$ was placed just downstream using the pole at the downstream part of the tail of the redd. The total surface of the redd was collected by successive substrate sheets of $4-6 \mathrm{~cm}$ until no more eggs were detected in the substrate sample. Each sheet (mixture substrate-eggs) collected downstream in the net was immediately sorted. The eggs were collected with tweezers, counted and preserved in absolute ethanol. The numbers of eggs collected per redd and the dates of first observation are given in Appendix 1. On 10 of these redds, a female showing spawning behaviour was observed. When the construction based on the shape and dimension of the redd appeared to be completed, all trout were caught in proximity by electrofishing. For every trout caught the sex, weight and forklength were recorded, fin tissue samples were collected and stored in absolute ethanol for DNA-analysis and scale samples were taken for age determination. After examination, trout were released at the place they had been caught. In some cases, males that were observed to behave as dominant males immediately before the electrofishing were caught (data not shown). Additional potential spawners were caught in September and in mid-December of 1995. In order to determine the body length-fecundity relationship, all ripening eggs and the fork length of 23 females caught in the Chevenne prior to spawning were recorded.

\subsection{Microsatellite analysis}

Individual DNA extractions were performed as described in Estoup et al. [18]. The degree of polymorphism of 10 salmonid microsatellites was first tested by genotyping about 15 adult individuals from the study site. The four loci (MST-591, T3-13, FGT1, AET1G) showing the highest level of variability were 
selected for genotyping the remaining samples of this study. These four loci have been confirmed to be unlinked and to follow Mendelian segregation in joint and single gene segregation studies (C.R. Largiadèr, unpublished data). PCRs were performed using a PTC100 machine (MJ Research, USA) with a heated lid and the electrophoresis was carried out on $6 \%$ denaturing polyacrylamide sequencing gels. The annealing temperature, the concentration of $\mathrm{MgCl}_{2}$ and the number of cycles were $54{ }^{\circ} \mathrm{C} 1.0 \mathrm{mM}$ and 24 for MST-591, $54{ }^{\circ} \mathrm{C}, 1.0 \mathrm{mM}$ and 27 for T3-13, $62{ }^{\circ} \mathrm{C}, 0.7 \mathrm{mM}$ and 30 for $\mathrm{FGT} 1$ and $59{ }^{\circ} \mathrm{C}, 0.8 \mathrm{mM}$ and 24 for AETG1, respectively. Detailed procedures for the radioactive end-labelling of primers and PCR amplification are given in Estoup et al. [19]. The primers used for amplification of MST-591 are given in Presa and Guyomard [43], for T3-13 in Estoup et al. [20], for FGT1 in Sakamoto et al. [47] and for AETG1 in Estoup et al. [19].

\subsection{Analysis of multiple paternity}

We developed the following sequential testing procedures, which does not require the knowledge of all paternal genotypes in the population, as is the case for maximum-likelihood based procedures [19], and which are based on the assumptions of Mendelian inheritance and independence of the analysed loci. As a first step, we verified that the genotype of the suspected maternal individual was coherent with the associated egg-genotypes: 1A) for each egg and at each locus, at least one allele was expected to be identical with one of the two alleles of the putative mother; 1B) deviation from the Mendelian proportions of the inferred maternal monolocus gametes was then tested (binomial test); 1C) for all pairs of loci, the same test or if the female was heterozygous at both loci a Fisher exact test was applied on inferred maternal bilocus gametes. Redds were excluded from further multiple paternity analysis as soon as one of the above tests was significant. Maternal alleles could not be strictly identified when a heterozygous egg had the same genotype as the maternal individual. For this situation, the tests $1 \mathrm{~B}$ and $1 \mathrm{C}$ were carried out assuming two extreme scenarios, i.e. that always the same allele was transmitted by the mother. The scenario with the highest probability was retained for later paternity analyses in order to minimise the number of assumed paternal alleles for subsequent paternity analysis.

For not rejected redds, the paternal gametes of individual eggs were inferred by subtracting the maternal alleles. To this data the following procedure was applied for the determination of paternal genotypes: 2A) assuming that all fathers were heterozygous for different alleles, the minimum number of fathering males per redd was deduced for each locus by dividing the number of observed alleles by two and rounding the result to the next integer; $2 \mathrm{~B}$ ) based on the highest number of fathering males obtained among all loci in the previous step, all possible combinations of paternal genotypes were deduced for each locus. 
Genotype combinations resulting in significant deviation of the inferred paternal gamete distributions from Mendelian proportions (binomial test) were excluded from further analysis; $2 \mathrm{C}$ ) based on the retained paternal monolocus genotypes, all possible paternal bilocus genotype combinations were formed for all pairs of loci. Genotype combinations were rejected if paternal bilocus gametes were observed in the egg sample that could not have been produced by these genotype combinations. Among the retained cases, all genotype combinations resulting in significant deviation of the inferred paternal bilocus gamete distributions from Mendelian proportions (Fisher Exact test or binomial test) were rejected. At this stage, it was possible to assign to each egg a single hypothetical father with a given bilocus genotype except for the rare cases of different fathers having identical bilocus gametes; 2D) the information obtained independently for all pairs of loci was combined by checking that the same father was assigned for each egg across all pairs of loci. Eggs with the same heterozygous genotype as the mother at a particular locus and for which the wrong maternal allele had been assigned prior to paternity analysis were expected to be detectable at this stage through inconsistent paternity assignments across pairs of loci. If inconsistencies could not be resolved, genetic contribution of an additional male should be assumed and tested by reapplying steps $2 \mathrm{~B}, 2 \mathrm{C}$ and $2 \mathrm{D}$.

\subsection{Analysis of spawner samples and of redd superimposition}

The expected heterozygosity $\left(H_{e}\right)$ was estimated as defined by Nei [38]. Deviation from Hardy-Weinberg equilibrium and genetic heterogeneity between samples were assessed by Fisher's exact test using the GENEPOP package version 3.2 [46]. Significance of multiple $P$-values were tested using the Fisher's method (GENEPOP package). Average probability of exclusion was calculated for each locus $\left(E_{l}\right)$ according to Chakravarti and $\mathrm{Li}[7]$ and global probability across all loci $\left(E_{g}\right)$ according to Chakraborty et al. [8]. It gives the average fraction of males that can be excluded from paternity with $L$ loci for a given mother/offspring pair if they are not the fathers.

The genetic analysis of redd superimposition was conducted on all 22 sampled redds. For each redd a minimum of 16 eggs were genotyped at two of the four loci (MST-591 and T3-13). Cases of redd superimposition were genetically unambiguously diagnosed if three eggs of the same sample did not have any alleles in common at a given locus. 


\section{RESULTS}

\subsection{Genetic variation of spawners}

No significant deviation from Hardy-Weinberg expectations were found at all loci in both samples of spawners (single locus $P$-values $>0.09$; multilocus $P$-value $=0.23$ and 0.37 for the upstream and the downstream section, respectively). Significant differentiation was found at three of four loci between the samples of the two sectors $(P$-Value $<0.007$ for T3-13, FGT1 and AET1G; $P$-value $=0.30$ for MST-591; multilocus $P$-value $<0.0001)$.

Number of alleles, heterozygosities and probabilities of exclusion are given in Table I for each locus and for each section. A high genetic variability is found at all four loci in both sections as is indicated by the high heterozygosity values and the high number of alleles found at each locus. Consequently, these loci combined yield high exclusion probabilities $>0.9$, thus indicating that they are powerful markers for the study of mating systems and parentage analysis. The generally lower values for the descriptive statistics in the upstream section as compared to the down stream section, probably results from the isolation of the upper part from the main course by the impassable waterfalls.

\subsection{Multiple paternity analysis}

Egg-genotypes conformed with genotypes of putative mothers in only four out of 10 redds available for this analysis (redds $17,74,89,124$ ). The very low maternal genotype probabilities (Tab. II), i.e. the expected frequencies of these genotypes in the population, indicated that the four mother-redd associations were likely to be correct. Six females were excluded as putative mother since a majority of the egg-genotypes of the associated redd had none of the female's alleles at one or more loci. A subsample of redd 17 contained several eggs with genotypes which did not conform with the genotype of the putative maternal female. Because this subsample represented the deepest part of the redd, these eggs probably originated from a redd which was created before a second female (the observed female) superimposed her redd. We therefore maintained this redd for the multiple paternity study and analysed all eggs of the upper substrate layers (65 eggs) and excluded those of the lowest layers (18 eggs).

The minimum number of fathering males inferred by direct counting of the paternal alleles independently at each locus was two for each of the four redds and the same number of fathering males was revealed by the multilocus procedure (Tab. II). The expected frequencies of the four-locus parental genotypes computed using allele frequencies estimated from the samples of potential spawners were very low (Tab. II). This indicates that each inferred parental 
Table I. Genetic variability at four microsatellite loci in the reference samples of brown trout spawners from the Chevenne. ( $N$ is number of individuals analysed; $H_{e}$ is expected heterozygosity; $E$ is average probability of exclusion. Allele frequencies are available from the authors upon request.)

\begin{tabular}{cllll}
\hline Locus & $N$ & Nb of alleles & $H_{e}$ & $E$ \\
\hline
\end{tabular}

Upstream section

$\begin{array}{ccccc}\text { MST-591 } & 25 & 6 & 0.516 & 0.330 \\ \text { T3-13 } & 24 & 13 & 0.824 & 0.666 \\ \text { FTG1 } & 25 & 8 & 0.674 & 0.450 \\ \text { AET1G } & 24 & 6 & 0.547 & 0.296 \\ \text { all loci } & & & & \mathbf{0 . 9 1 3}\end{array}$

Downstream section

\begin{tabular}{ccccc} 
MST-591 & 66 & 12 & 0.720 & 0.542 \\
T3-13 & 66 & 17 & 0.799 & 0.640 \\
FTG1 & 66 & 16 & 0.763 & 0.574 \\
AET1G & 66 & 15 & 0.739 & 0.541 \\
all loci & & & & $\mathbf{0 . 9 6 8}$ \\
\hline
\end{tabular}

genotype most likely represents a single individual, and thus, that we identified all males which fertilised the egg samples. For each redd the relative contribution of the different fathers was similarly distributed with one male having fertilised the majority of the eggs (60-92\%) and an additional male having fertilised between $8 \%$ and $40 \%$ of the eggs (Tab. II). One case of matching four-locus genotypes was found when comparing inferred male genotypes with the genotypes of the reference sample of spawners. It concerned the hypothetical fathering male of redd 124 which was estimated to have fertilised $86 \%$ of the eggs of this redd. A correct identification of this particular male was highly probable because this male had been observed as being the dominant male on redd 124 before it was captured.

Two particular cases were encountered when applying the procedure of multilocus multiple paternity analysis, both concerning locus FTG1: (i) trigenic genotypes were recorded at this locus for 14 eggs of redd 17 . Whether these 
Table II. Multiple paternity analysis of four polyandrous brown trout redds using four microsatellite loci. ( $N$ is number of eggs analysed. Maternal genotypes are shown in bold. $P_{G}$ is the genotype probability, i.e. the expected frequency of a genotype based on allele frequencies in the reference sample of spawners and $C_{P}$ is the estimated percentage of fertilised eggs by hypothetical males inferred by the multilocus procedure. Allele sizes are given in bp. Egg genotype data are available from the authors upon request.)

\begin{tabular}{|c|c|c|c|c|c|c|c|c|c|c|c|c|}
\hline \multirow{3}{*}{ Redd } & \multirow{3}{*}{$N$} & \multicolumn{4}{|c|}{ Allele counting method } & & \multicolumn{6}{|c|}{ Multilocus method } \\
\hline & & \multicolumn{4}{|c|}{$\begin{array}{l}\text { Minimum number of paternal individuals } \\
\text { (Number of observed paternal alleles) }\end{array}$} & & \multicolumn{4}{|c|}{ Maternal and paternal genotypes } & \multirow[t]{2}{*}{$P_{G}$} & \multirow[t]{2}{*}{$C_{P}$} \\
\hline & & MST-591 & $\mathrm{T} 3-13$ & FTG1 & AET1G & & MST-591 & $\mathrm{T} 3-13$ & FTG1 & AET1G & & \\
\hline \multicolumn{13}{|c|}{ Upstream section } \\
\hline \multirow[t]{3}{*}{124} & 36 & $2(3)$ & $2(3)$ & $1(2)$ & $1(2)$ & & 194-198 & 191-209 & $237-251$ & 306-388 & $2.0 \times 10^{-6}$ & \\
\hline & & & & & & Male 1 & $166-198$ & $191-191$ & $205-241$ & $388-388$ & $8.2 \times 10^{-5}$ & $86.0 \%$ \\
\hline & & & & & & Male 2 & $170-198$ & $205-249$ & $205-241$ & $306-388$ & $4.2 \times 10^{-5}$ & $14.0 \%$ \\
\hline \multicolumn{13}{|c|}{ Downstream section } \\
\hline \multirow[t]{3}{*}{17} & 65 & $1(2)$ & $2(4)$ & $1(2)$ & $2(4)$ & & 174-194 & 209-209 & 205-233 & 306-306 & $4.1 \times 10^{-7}$ & \\
\hline & & & & & & Male 1 & $194-194$ & 197-209 & $241-241$ & $314-388$ & $1.6 \times 10^{-7}$ & $92.3 \%$ \\
\hline & & & & & & Male 2 & $150-194$ & $191-217$ & $205-241$ & $394-406$ & $1.7 \times 10^{-7}$ & $7.7 \%$ \\
\hline \multirow[t]{3}{*}{74} & $45^{*}$ & $1(2)$ & $2(3)$ & $2(4)$ & $2(4)$ & & 166-198 & 209-237 & $205-241$ & 306-372 & $4.3 \times 10^{-7}$ & \\
\hline & & & & & & Male 1 & $150-194$ & $193-217$ & 205-235 & $306-354$ & $1.2 \times 10^{-8}$ & $60.0 \%$ \\
\hline & & & & & & Male 2 & $150-194$ & 191-191 & 241-243 & $388-394$ & $6.0 \times 10^{-6}$ & $40.0 \%$ \\
\hline \multirow[t]{3}{*}{89} & 30 & $2(3)$ & $1(2)$ & $2(3)$ & $1(2)$ & & 152-194 & 213-239 & $235-241$ & 306-342 & $5.4 \times 10^{-8}$ & \\
\hline & & & & & & Male 1 & $170-170$ & 191-239 & 205-205 & $388-388$ & $1.1 \times 10^{-5}$ & $67.4 \%$ \\
\hline & & & & & & Male 2 & $192-194$ & 191-191 & $\varnothing-205$ & 388-394 & $11 \times 10^{-5}$ & $32.6 \%$ \\
\hline
\end{tabular}

\footnotetext{
* two eggs did not amplify.
} 
genotypes resulted from partial or complete triploidy or from a duplicated locus could not be determined. The trigenic genotypes contained both maternal alleles and if we assumed the third allele as paternal contribution, a pair of male genotypes could be determined at this locus with the multilocus procedure that was congruent with the paternity assignment based on the other three loci; (ii) redd 89 also contained two eggs showing trigenic genotypes with both maternal alleles at FTG1. A pair of paternal genotypes at this locus that were consistent with the results based on the other loci, could only be determined by assuming the presence of a non-amplifying allele [42] at this locus for particular eggs. It concerned all eggs showing the same heterozygous genotype as the putative mother.

\subsection{Fecundity and redd superimposition}

We found that egg number and body length (forklength) were significantly correlated for female spawners of the Chevenne $\left(P<0.0001, R^{2}=0.687\right)$ and the relationship was described by the following linear regression function: Number of eggs $=4.165 \times$ Forklength $[\mathrm{mm}]-598.846$. Based on this function, the number of eggs found in the four redds listed in Table II represented approximately $17.6 \%, 16.4 \%, 21.4 \%$, and $10.6 \%$ of the total fecundity of the females. This result suggested that the females spread their eggs among 5-10 different redds.

Taking into account all eggs analysed at the two loci (Append. 1), eight cases of redd superimposition were genetically detected among 22 redds. By applying Mann-Whitney U tests, we tested the hypotheses (i) that the detection of redd superimposition was dependent on the number of eggs analysed and (ii) that more dead eggs should be found in superimposed redds as consequence of the physical disturbance during overdigging. The average number of analysed eggs was not significantly higher for superimposed redds $(P=0.0675)$ as compared to redds for which no superimposition had been detected. Finally, significantly more dead eggs were found in the superimposed redds $(P=0.0375)$.

\section{DISCUSSION}

\subsection{Polyandry in brown trout}

Polyandry through successful fertilisation by presumably subdominant males appeared to be very common in the investigated sedentary brown trout population, since all four redds which could be analysed for this purpose were found to be polyandrous. The small number of redds analysed did, however, 
not allow to infer an accurate estimate of the rate of polyandrous redds in this population. Two explanations were possible for the high number of redds (6 out of 10) for which the putative mothers were rejected on the basis of our female verification protocol: (i) a caught female was wrongly identified as the observed spawning female or (ii)that in these cases, eggs from superimposed redds of different females had been sampled. The second explanation appeared to be more likely to account for most of these cases because of the high rate of redd superimposition that was observed in this study including four of the six rejected redds and because our female verification procedure would also reject putative mothers if some of the eggs actually belonged to these individuals. Furthermore, the identification of the observed female among all caught trout on the basis of size and coloration appeared to be unambiguous for these cases.

Studies concerning spawning success of subdominant males in the sister species Atlantic salmon indicated that subdominant males generally fertilise less eggs than the dominant males. Single, sneaking male parr were found to fertilise on average $5 \%$ of the eggs in a redd and the percentage of eggs per redd fertilised by male parr ranged between 1-28\% using allozyme markers [26,31]. Much higher estimates of $25-89 \%$ of the eggs fertilised per redd by male parr with individual parr fertilising up to $47 \%$ of the eggs were obtained in studies using minisatellite and/or microsatellite DNA markers [34,37,51]. However, in a recent study with sockeye salmon, no significant difference was found in spawning success between subdominant and alpha males, and that single subdominant males fathered up to $93 \%$ of the offspring [21]. Therefore, it seemed unreasonable to assume in our case that the majority of eggs was always fertilised by a dominant male. This meant we could not assign the estimated genetic contributions of the inferred paternal genotypes (Tab. II) unambiguously to a dominant or a subdominant male with the exception of redd 124 . In this case, the observed dominant male had been caught and was identified as being the male having fertilised $86 \%$ of the eggs. The low number of eggs found in the redds as compared to the estimated female fecundity indicated that these redds represent one single egg pocket, i.e. one single spawning event. Thus, the possibility that an egg sample represented two separate egg pockets of the same female fertilised by two consecutive dominant males was very unlikely. Taking this into account, the detection of subdominant males having fertilised at least between $8-40 \%$ of the eggs among the four redds analysed (Tab. II) appeared to be very probable.

So far, studies investigating polyandry in salmonid species using genetic markers have focused on anadromous or partially anadromous populations and more precisely on various factors influencing the spawning success of small sneaker (usually resident) males in competition with large dominant and migratory males $[21,26,31,34,37,51]$. Thus there is no genetic information regarding spawning success of larger subdominant males, i.e. fighting satellite males. This kind of male competition is expected to play an important role especially in stream resident populations such as the Chevenne population. In general, 
males of intermediate size are rare in partial migratory salmonid populations which can be explained by negative frequency-dependent, disruptive selection that eliminates intermediate male sizes because they would be to small to compete with the large fighting males and too large for sneaking [22]. Secondly, females show higher tendency for migration than males in these populations which leads to biased sex ratios for small spawners, dominated by males, and for large spawners, dominated by females $[30,39]$. This taken together, results in large differences in body size distribution in males and in females as compared to stream resident populations. In the sedentary Chevenne population, a rather continuous body size distribution for males and females is observed (Champigneulle and Largiadèr, unpublished data) and, therefore, less biased sex ratios are expected in different size classes. Sneaking may therefore be less frequent in sedentary than in partial migratory populations or even not occur, especially if size assortative mating exists as was observed in Japanese charr [33]. In the case of the Chevenne population, we expect that some sneaking probably occurs because the smallest observed mature male was only $25 \%$ of the body length of the largest mature male (data not shown). This size difference is within the range that is found between sneaking and alpha males in other salmonids [26].

\subsection{Competition between females}

The estimate of $36 \%$ of superimposed redds in this study indicates considerable competition for favourable spawning sites between females. The importance of this indirect competition [24] may be further underlined, if we consider that this estimate represents a strong under-estimation of the actual rate for two reasons. Firstly, the genetic analysis of redds allows only to detect cases of redd superimposition which resulted in incomplete replacement of the original redd. Secondly, it is likely that we were not able to detect all cases of incomplete superimposition on the basis of two loci only and by not analysing the entire egg samples for all redds.

Studying Atlantic salmon in an experimental spawning channel, Beall and Marty [4] found that redd superimposition increased with increasing density of spawners. A high superimposition rate, however, may not simply indicate a lack of adequate spawning sites. Contagious redd distributions observed for pink salmon in an experimental spawning channel [36] and for co-occurring brown and rainbow trout populations [24] suggest that other factors than spawner density also influence the superimposition rate. Theoretically, redd construction improves the physical conditions for spawning at this particular site through cleaning the substrate from fine particles and thus making it more attractive for later spawners. This increases the probability of multiple use of this site for spawning and leads to contagious distribution of redds. 
A third factor which influences the overdigging rate, is the length of spawning season. In the case of a coho salmon population, it was suggested that the length of the spawning season results from selection against offspring of both early and late spawners [52]. Early spawners are disadvantaged by increased risk of egg mortality through redd superimposition but their offspring have selective advantage because they hatch first and have better access to highquality feeding territories $[35,52]$. As a consequence, there should be selection for a short spawning period. However, we speculate that unstable environmental conditions during spawning season and during early life stages of salmonids should favour long spawning seasons, since survival of offspring of late and early spawners should vary considerably among years under such conditions. Unstable environmental conditions may be caused through strong fluctuations in water discharge in streams resulting high mortality of eggs and young stages in salmonids populations, e.g. through shifting of gravel [14]. In fact, spates causing strong streambed movements were observed in the Chevenne during the spawning season and during snow melt in early spring when young trout smerge from the streambed (A. Champigneulle, pers. obs.). Unstable envionmental conditions, therefore, represent a probable explanation for the long spawning season (over two months) observed in the Chevenne population and sonsequently the observed redd superimpositions may be largely explained by 'he extensive spawning season.

\subsection{Multiple-redd tactic?}

Barlaup et al. [4] estimated that females of anadromous brown trout poplation spread their eggs on average among 5.7 redds, representing $17.4 \%$ of ;heir total fecundity per redd, which is similar to values estimated for four edds in this study (11-21\%; Tab. II). Their calculations suggest that tempoal and spatial variation in offspring survival results in a selective advantage for nultiple-redd tactics over single-redd tactic. Consequently, they hypothesised hat the spread of offspring among different redds is an adaptive behaviour in ivers characterised by large temporal fluctuations in conditions affecting egg :urvival. It seems reasonable to propose the same hypothesis for the Chevenne sopulation, because, as mentioned previously, strong fluctuations of water disharge resulting in the destruction of redds have been observed in this stream. Iowever, presently two other explanations could be valid for such a behaviour: i) spawning substrate patches could generally be too small for the deposition $f$ all eggs, so that the females are forced to spread their eggs among several atches, or (ii) that a high female density, and hence strong direct competition or spawning sites, does not allow for most females to defend a spawning place ong enough to spawn all eggs.

It is noteworthy, that the number of redds per female estimated based on gg counts in redds and female fecundity data (e.g. [4], this study) should be 
regarded as an overestimation of the true number for several reasons. Some eggs may be lost during the spawning act or by ova retention which appears to increase with female size and female density $[5,40]$. Such losses were found to range between 0 and $24 \%$ of the in brown trout [16]. Furthermore, egg number laid in redds may further decrease over time due to washout by spates [11], predation by fish and invertebrates, and decomposition of dead eggs. Such losses probably vary among populations and redds, however, the observations of one redd per female based on the same method in other brown trout populations $[23,25]$ suggest that such losses are on average moderate.

\section{Conclusions}

Whatever might be the evolutionary background of the observed polyandry, redd superimposition and the spreading of eggs among several redds by individual females, all three may have considerable influence on the effective population size $\left(N_{e}\right)$. They are therefore of general interest in the context of conserving the genetic diversity in small and threatened brown trout populations. The estimated relative contribution of presumably subdominant males to the offspring is considerably high and therefore should have a strong positive effect on $N_{e}$ [49]. The role of redd superimposition and the multiple redds per female remains unclear, since theoretically both factors can have either positive or a negative effects on $N_{e}$ depending on the circumstances. For example, if all possible spawning sites have been used, redd superimpositions resulting in incomplete destruction of prior redd should increase the total number of reproducing females as compared to the same situation with no overdigging; and an increasing number of redds per female increases the chance of redd superimpositions but also increases the probability for direct competition between females for a spawning site, and hence, may force more females to spawn at less attractive sites leading to higher number of spawning sites used by a population.

\section{ACKNOWLEDGEMENTS}

This work was supported by the program "Recherches méthodologiques pour l'amélioration des processus de gestion et de conservation des ressources génétiques animales, végétales et microbiennes" of the Bureau des ressources génétiques. 
Appendix 1. Genotypes at two micosatellite loci found in brown trout egg samples from 22 redds. $(*$ : redds for which the genotypes were found that indicate superimposition of a second redd. Date is the date of the first observation of the redd, $N$ is total number of eggs found in a redd, $N_{D}$ is number of dead eggs, and $N_{A}$ is number of analysed eggs. Allele sizes are given in bp.)

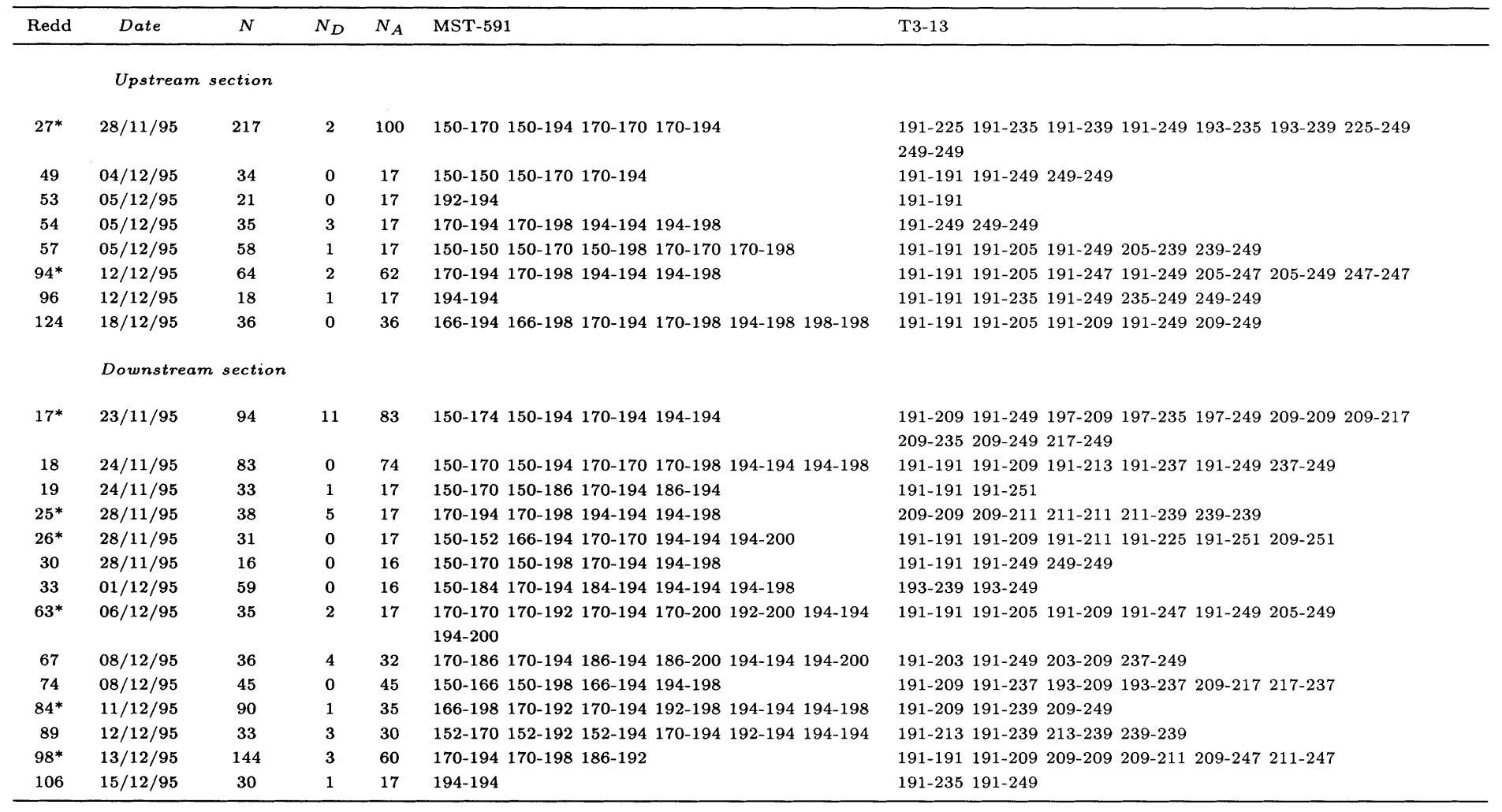




\section{REFERENCES}

[1] Andersson M., Sexual Selection, Princeton University Press, New Jersey, 1994.

[2] Allendorf F.W., Waples R.S., Conservation and genetics of salmonid fish, in: Avise J.C., Hamrick J.L. (Eds.), Conservation genetics: case histories from nature, Chapman and Hall, New York, 1996, pp. 238-255.

[3] Bagliniere J.-L., Champigneulle A., Nihouarn A., La fraie du saumon atlantique (Salmo salar L.) et de la truite commune (Salmo trutta L.) sur le bassin du Scorff, Cybium 7 (1979) 75-96.

[4] Barlaup B.J., Lura H., Saegrov H., Sundt R.C., Inter- and intra-specific variability in female salmonid spawning behaviour, Can. J. Zool. 72 (1994) 636-642.

[5] Beall E., Marty C., Optimisation de la reproduction naturelle du saumon atlantique en chenal de fraie : influence de la densité des femelles, in: Thibault M., Billard R. (Eds.), Restauration des rivières à saumons, Inra, Paris, 1987, pp. 231-238.

[6] Clapham P.J., Palsboll P.J., Molecular analysis of paternity shows promiscous mating in female humpback whales (Megaptera novaengeliae, Borowski), Proc. R. Soc. Lond. [Biol.] 264 (1997) 95-98.

[7] Chakravarti A., Li C.C., The effect of linkage on paternity calculations, in: Walker R.H. (Ed.), Inclusion probabilities in parentage testing, American Association of Blood Banks, Arlington, 1983, pp. 411-420.

[8] Chakraborty R., Shaw M.W., Schull W.J., Exclusion of paternity: The current state of the art, Am. J. Hum. Genet. 28 (1974) 477-488.

[9] Chesser R.K., Gene diversity and female philopatry, Genetics 127 (1991) 437-447.

[10] Chesser R.K., Influence of gene flow and breeding tactics on gene diversity within populations, Genetics 129 (1991) 573-583.

[11] Crisp D.T., Use of artificial eggs studies of washout depth and drift distances for salmonid eggs, Hydrobiologia 178 (1989) 155-163.

[12] Crisp D.T., Carling P.A., Observations on siting, dimensions and structure of salmonid redds, J. Fish Biol. 34 (1989) 119-134.

[13] Davies N.B., Mating systems, in: Krebs J.R., Davies N.B. (Eds.), Behavioural Ecology, Blackwell Scientific Publications, Oxford, 1991, pp. 263-294.

[14] Elliott J.M., The downstream drifting of eggs of brown trout, Salmo trutta L., J. Fish Biol. 9 (1976) 45-50.

[15] Elliott J.M., Quantitative Ecology and the Brown Trout, Oxford University Press, Oxford, 1994.

[16] Elliott J.M., Fecundity and egg density in the redd of sea trout, J. Fish Biol. 47 (1995) 893-901.

[17] Estoup A., Rousset F., Michalakis Y., Cornuet J.-M., Adriamanga M., Guyomard R., Comparative analysis of microsatellite and allozyme markers: a case study investigating microgeographic differentiation in brown trout (Salmo trutta), Mol. Ecol. 7 (1998) 339-353.

[18] Estoup A., Largiadèr C.R., Perrot E., Chourrout D., Rapid one tube DNA extraction for reliable PCR detection of fish polymorphic markers and transgenes, Mol. Marine Biol. Biotech. 5 (1996) 295-298.

[19] Estoup A., Gharbi K., SanCristobal M., Chevalet C., Haffray P., Guyomard R., Parentage assignment using microsatellites in turbot (Scophtalmus maximus) and 
rainbow trout (Oncorhynchus mykiss) hatchery populations, Can. J. Fish. Aquat. Sci. 57 (1998) 715-723.

[20] Estoup A., Solignac M., Cornuet J.M., Precise assessment of the number of patrilines and of genetic relatedness in honey bee colonie, Proc. R. Soc. Lond. [Biol.] 258 (1994) 1-7.

[21] Foote C.J., Brown G.S., Wood C.C., Spawning success of males using alternative mating tactics in sockeye salmon, Oncorhynchus nerka, Can. J. Fish. Aquat. Sci. 54 (1997) 1785-1795.

[22] Gross M.R., Disruptive selection for alternative life histories in salmon, Nature 313 (1985) 47-48.

[23] Hardy C.J., An examination of eleven stranded redds of brown trout (Salmo trutta), excavated in the Selwyn River during July and August 1960, New Zealand J. Sci. 6 (1963) 107-119.

[24] Hayes J.W., Competition for spawning space between brown trout (S. trutta) and rainbow trout ( $S$. gairdneri) in a lake inlet tributary, New Zealand, Can. J. Fish. Aquat. Sci. 44 (1987) 40-47.

[25] Hobbs D.F., The natural reproduction of quinnat salmon, brown and rainbow trout in certain New Zealand waters, Fish. Bull. Wellington, N.Z. 6 (1937) 1-104.

[26] Hutchings J.A., Myers R.A., Mating success of alternative maturation phenotypes in male Atlantic salmon, Salmo salar, Oecol. 75 (1988) 169-174.

[27] Jones J.W., Ball J.N., The spawning behaviour of brown trout and salmon, Br. J. Animal Behav. 2 (1954) 103-114.

[28] Jones A.G., Avise J.C., Polygynandry in the dusky pipefish Syngnathus floridae revealed by microsatellite DNA markers, Evolution 51 (1997) 1611-1622.

[29] Jones A.G., Ostlund-Nilsson S., Avise J.C., A microsatellite assessment of sneaked fertilizations and egg thievery in the fifteenspine stickleback, Evolution 52 (1998) 848-858.

[30] Jonsson B., Jonsson N., Partial migration: Niche shift versus sexual maturation in fishes, Rev. Fish Biol. Fish. 3 (1993) 348-365.

[31] Jordan W.C., Youngson A.F., The use of genetic marking to assess the reproductive success of mature male Atlantic salmon parr (Salmo salar L.) under natural spawning conditions, J. Fish Biol. 41 (1992) 613-618.

[32] Kellogg K.A., Markert J.A., Stauffer J.R., Kocher T.D., Microsatellite variation demonstrates multiple paternity in lekking cichlid fishes from Lake Malawi, Afrika, Proc. R. Soc. Lond. [Biol.] 260 (1995) 79-84.

[33] Maekawa K., Nakano S., Yamamoto S., Spawning behaviour and size-assortative mating of Japanese charr in an artificial lake-inlet stream system, Environ. Biol. Fishes 39 (1994) 109-117.

[34] Martinez J.L., Moran P., Perrez J. De Gaudemar B., Beall E., Garcia-Vasquez E., Multiple paternity increases effective size of southern Atlantic salmon populations, Mol. Ecol. 9 (2000) 293-298.

[35] Mason T.C., Chapman D.W., Significance of early emergence, environmental rearing capacity, and behavioral ecology of juvenile coho salmon in stream channels, J. Fish. Board Can. 22 (1965) 173-190.

[36] McNeil W.J., Randomness in distribution of pink salmon redds, J. Fish. Board Can. 24 (1967) 1629-1634. 
[37] Moran P., Pendas A.M., Beall E., Garcia-Vazquez E., Genetic assessment of the reproductive succes of Atlantic salmon precocious parr by means of VNTR loci, Heredity 77 (1996) 655-660.

[38] Nei M., Estimation of average heterozygosity and genetic distance from a small number of individuals, Genetics 89 (1978) 583-590.

[39] Northcote T.G., Migration and residency in stream salmonids - some ecological considerations and evolutionary consequences, Noric. J. Freshw. Res. 67 (1992) $5-17$.

[40] O'Farrel M.M., Wheland K.F., Wheland B.J., A preliminary appraisal of the fecundity of migratory trout (Salmo trutta) in the Erriff catchment, western Ireland, Pol. Arch. Hydrobiologii 36 (1989) 273-281.

[41] Ottaway E.M., Carling P.A., Clarke A., Reader N.A., Observations on the structure of brown trout, Salmo trutta Linnaeus, redds, J. Fish Biol. 19 (1981) 593-607.

[42] Pemberton J.M., Slate J., Bancroft D.R., Barrett J.A., Non amplifying alleles at microsatellite loci: a caution for parentage and population studies, Mol. Ecol. 4 (1995) 249-252.

[43] Presa P., Guyomard R., Conservation of microsatellites in three species of salmonids, J. Fish Biol. 49 (1996) 1326-1329.

[44] Primmer C.R., Møller A.P., Ellegren H., Resolving genetic relationships with microsatellite markers: A parentage testing system for the swallow Hirundo rustica, Mol. Ecol. 4 (1995) 493-498.

[45] Reynolds J.D., Animal breeding systems, TREE 11 (1996) 68-72.

[46] Raymond M., Rousset F., GENEPOP (version 1.2): Population genetics software for exact test and ecumenicism, J. Hered. 86 (1995) 248-249.

[47] Sakamoto T., Okamoto N., Ikeda Y., Nakamura Y., Sato T., Dinucleotide-repeat polymorphism in DNA of rainbow trout and its application in fisheries sciences, J. Fish Biol. 44 (1994) 1093-1096.

[48] Soulé M.E., What do we really know about extinction?, in: Schonewald-Cox C.M., Chambers S.M., MacBryde B., Thomas L. (Eds.), Genetics and conservation, The Benjamin/Cummings Publishing Company Inc, London, 1983, pp. 111-124.

[49] Sugg D.W., Chesser R.K., Effective population sizes with multiple paternity, Genetics 137 (1994) 1147-1155.

[50] Taborsky M., Sneakers, satellites, and helpers: Parasitic and cooperative behavior in fish reproduction, Adv. Stud. Behav. 23 (1994) 1-100.

[51] Thomaz D., Beall E., Burke T., Alternative reproductive tactics in Atlantic salmon factors affecting mature parr success, Proc. R. Soc. Lond. [Biol.] 264 (1997) 219-226.

[52] Van den Berghe E.P., Gross M.R., Natural selection resulting from female breeding competition in a pacific salmon (coho: Oncorhynchus kisutch), Evolution 43 (1989) 125-140. 